\title{
A CRITIQUE OF COLLECTIVE BARGAINING POLICY IN NIGERIA FROM COLONIAL ERA TILL DATE
}

\section{DOI: 10.36108/ljerhrm/2202.03.0130}

\author{
FAJANA, Issa Olusola PhD \\ Department of Employment Relations \& Human Resource Management \\ Faculty of Management Sciences \\ University of Lagos \\ solafajana@yahoo.com \\ and

\section{ELEGBEDE, Sikirullah Tunde PhD} \\ Department of Employment Relations \& Human Resource Management \\ Faculty of Management Sciences \\ University of Lagos \\ telegbede@unilag.edu.ng
}

\begin{abstract}
This study focused on a critical evaluation of collective bargaining policy in Nigeria from the historical perspective. The main objective of this study was to evaluate the structure and system of collective bargaining in Nigeria since the colonial period. The study adopted a conceptual analysis and theoretical explanation of the origin, development, weakness, and state involvement in collective bargaining policy in Nigeria through a critical review of extant literatures. The study revealed that collective bargaining as machinery for wage determination in the public sector is supposed to prevent the unilateral imposition of wages on the union by the government and vice versa as the case may be. However, it is not often used by the Nigerian government to determine wages rather government relied more on wage commissions, wage tribunals, and civil services administrative rules to determine wages in the public sector. Therefore, collective bargaining appears to be ineffective as a potent tool for wage determination in Nigeria's public sector. The study also discovered that collective bargaining machinery in Nigeria is weak because of government's direct involvement in collectivebargaining process to review, amend, even absolutely reject the collective agreement reached between unions and the government representative at the bargaining table. The study, therefore, concluded that collective bargaining is not an effective institution within the context of employment relations in Nigeria.

Keywords: Employment Relations, Collective Bargaining, Trade Unions, Colonial Authority, wage tribunal, civil service administration

\section{Introduction}

Neo-classical economists' analyses of wage determination through the competitive labor market did not take into account the very important fact, that many labor markets are not competitive There is a considerable presence of distortions caused by non-competitive institutional elements such as trade unions, and collective bargaining (Fajana; 2000). The alterations of the labor market can bring about the imposition of the unions on firms, or the firms on the union. But an alternative approach that
\end{abstract}


involves both the unions and firms is what is referred to as collective bargaining (Fajana, 2000). The success of collective bargaining depends on the strength of collectivity of workers and the aggregation of several individuals' needs into a single programme of demands.

However, the unions' objective is to ensure through collective bargaining higher wages and better conditions of work. As Freeman and Medoff (1984) opined that; "Trade unions bargain for higher wages, equal pay, fair working conditions, or employment protection"

\section{Review of Literatures}

In explaining the role of collective bargaining in the public sector wage determination, there is a need to explore its history and development in Nigeria from 1937 till date. The late development of wage employment accounts for the late development of trade unions and other institutions and processes in industrial relations in Nigeria such as collective bargaining (Fashoyin; 1992, Fajana; 2000, Otobo; 2013).

Fashoyin (1992) noted that industrial relations in Nigeria began in the public sector as a result of the near absence of a private sector organization in Nigeria. This accounts for the late development of wage employment. Wage employment came with industrialization and commercialization that started in the 1940s which were introduced in the colonial public sector (Yesufu; 1984).

In his view ,Otobo (1986) raised four valid observations concerning the origin and development of wage employment; (i) that a colonial but largely urban-based administrative framework was established in 1861 when Lagos was annexed by Britain which, coupled with flourishing commercial activities, served to produce wage employment; (ii) that the actual military conquest of Nigeria spilled over to the second decade of the twentieth century, so that an effective administrative apparatus only became operational during the 1920s and 1930s. This led to the creation of a nascent national proletariat since as many as 227,451 were reported to be employed in the public sector alone by 1936; (iii) that the late introduction of currency notes and coins as the medium of exchange , as well as the extensive use of forced labour and convict labour, meant that insufficient attention was paid to the payment of regular wages until the 1920s, when the administration's owned employees ( Europeans \& Africa) were sufficiently organized to press for better terms of employment; (iv) that racial discrimination and rivalry, as lopsidedly reflected in pay differentials and fringe benefits , such as orbits of coercive comparisons as African employees pushed for equal treatment.

Otobo (2007) opined further that the absence of wage employment and the pattern of work relations account for the late development of trade unions in Nigeria, and subsequently collective bargaining. The origin of collective bargaining can be traced to the legal recognition of trade unions in 1938 in the public sector. As noted by Fashoyin (1992) that private sector companies in Nigeria were not unionized until 1946. In all, the history of collective bargaining in Nigeria can be linked with the legal recognition of trade unions in 1937. As argued by Fashoyin (1992) "in any event, the earliest evidence of joint negotiations or joint consultation in the country was in 1937 when the colonial government established provincial wage committees throughout the country"

The function of the wage committee was to undertake periodic wage reviews forr daily paid employees in the public sector. The committee composed mainly of government officials and this 
make wage determination a unilateral decision (Yesufu; 1984). In 1942, due to agitation and dissatisfaction among workers, the colonial government expanded the committee to include workers' representatives (Yesufu; 1984). Even though the roles of wage committees were mainly advisory, Fashoyin (1992) asserts that the inclusion of workers representatives in the provincial wage committees could be regarded as the origin of collective bargaining in the Nigerian public sector (Fajana; 2000)

Fundamentally, the provincial wage committees were used as political instruments of the contending political parties of the period (Fashoyin; 1984). With the general strike of 1945 and the growing disenchantment of trade unions, it became apparent that the provincial wage committees were grossly inadequate in meeting the aspiration of workers. As noted by Fashoyin (1992) the committees were used by daily paid workers who represented only a small fraction of the total workforce in the public service. And in the case of established staff, there was no machinery for bipartite wage determination. For these reasons, the WhitelyCouncil system was introduced in 1948, which had been in use in the United Kingdom.

The recommendation for its establishment was contained in two reports by Mr. Cowan, of the British Ministry of Labour and NationalService. Basically, three councils were catering for senior, junior staff, and technical employees. Each council functioned as a negotiating as well as dispute-settling machinery in the public service. Although Whitleyism was structurally a traditional bargaining machinery covering federal, state, and sometimes local government employees (Fashoyin; 1992) but the system failed in many government establishments (Otobo; 2007).

Yesufu (1962) and Fashoyin (1992), observed that Whitleyism failed in the public sector. This is because the machinery was used as consultative bodies rather than bargaining machinery. Again, there were problems of representation on union sides, indecision, red-tapism, and lack of government support.

Furthermore, they were rendered useless because the decisions on wages and conditions of employment were made by semi-political wage commissions, particularly for public employees. The provincial wage committees were introduced initially to determine the rate of pay of daily-paid employees in the public sector and were generally made up of government representatives alone. The scope and structure of the committees were substantially reviewed in 1942 to covered salaried employees and their representatives.

Fashoyin (1992) opined that this marked the beginning of collective bargaining in the public sector. The provincial wage committee achieved minimal success because the policy conflicted with civil service practices and the sovereign principle. Moreover, employees' representatives on the committee made little impact on the outcome of committees' deliberations, for lack of basic tenets of the collective relations in public employment (Fashoyin; 1992).

The general strike of 1945 and the growing desire of the workers to participate in the determination of their conditions of employment necessitate the government to introduce the Whitley Council system in 1948. The Whitley system comprised three councils - 1, 2 and 3 for senior, junior and industrial employees respectively. 
The National Public Service Negotiating Councils is subdivided into three councils.

Council I: Used by the management (official) side represented by the Establishment'spartments of the Federal and State Governments. On the workers' (staff) side the Association of Senior Civil Servants of Nigeria (ASCSN) whose members are drawn from grade levels 07-14 at the Federal and State Civil Services. The ASCSN approximates the senior staff association in the private sector.

Council II: Used by the management (official) side. This is made up as in council I above. 'On the staff side, there are two unions NCSU (Nigerian Civil Service Union) and NUCSTSAS (Nigerian Union of Civil Service Typists, Stenographic and Allied Staff). Employees covered by this council are drawn from the clerical, secretarial, executive and non-industrial cadres usually on grade levels 01-06.

Council III: Used by the management side as in councils 1and 2 above. On the staff side are five unions namely: The Civil Service Technical Workers Union of Nigeria (CSTWUN), Printing and Publishing Workers Union (PPWU), National Association of Nigerian Nurses and Midwives (NANNM), Medical and Health Workers Union, Customs Excise and Immigration Staff Union (proscribed in 1988).

The functions of the councils include:

i- Provision of the best means for utilising the ideas and experience of the staff;

ii- Means of securing to the staff a greater share in, and responsibility for the determination and observance of the conditions under which their duties are carried out;

iii- Determination of the general principle governing conditions of service e.g., recruitment, hours of work, promotion, discipline tenure, remuneration and superannuation

iv- A cursory examination of the above function suggests that it demonstrate the principle of bilateral relations and also an indication of the commitment of the colonial government to have a constant dialogue over employment conditions with the employees.

This is an indication of the paternalistic process of government in labour relations in the public sector by which both parties according to Fashoyin (1992) misunderstood the purposes and limits of the Whitley Councils. He emphasized further on the first function of the council that" while any group of employees would welcome an employer that seeks its views on methods of improving management process, that does not necessarily create a favourable atmosphere for labour-management relationships, more so when it is realised that the councils were empowered to discuss general principles concerning employment issues, but no individual cases or grievances were allowed to be discussed”.

It is very important to note that in the public sector collective bargaining decisions of the councils were to be reported to the government and thereupon shall become operative subject to the overriding authority of the head of state and subject to the approval of the legislature where necessary. In the public sector collective bargaining, there exists a chain of the decision-making process which may originate from the negotiating table but goes on to the various governmental agencies up to the highest levels in the public authority. The ultimate law-makingauthority (legislature) was often responsible for finalising the decisions of the whitely councils in most cases. Fashoyin noted that this unique method of labour management dialogue and decision-making clearly: makes the outcome of negotiations completely different from the private sector. He opines further 
that in the private sector, the nature and scope of union-management relations were constitutionally restricted.

\section{Method}

The study is a conceptual analysis of issues surrounding the evolution of collective bargaining in Nigeria from a critical perspective. Therefore, the study relied heavily on extant literature that covered collective bargaining policy in the Nigeria public sector with the view to critically evaluate the process.

\section{Discussions and critical issues in the Nigeria system of Collective Bargaining}

Fashoyin (1982), on two accounts, rguedthat two major factors inhibited the performance of the Whitley councils in the public sector. The first was the unfavourable responses of the civil servants to trade unionism and what it sought to achieve. The first and the largest union in the public sector, the Civil Service Union (CSU) was organised in 1912 mainly in response to the organization of similar bodies in other west African colonies (Yesufu;1984, Fashoyin; 1992). As noted by Fashoyin the CSU was not a protest organization for it was not founded based on any felt deprivation. Indeed, the employment conditions of the civil servants of the period were the best available.

Furthermore, employees in the civil service enjoyed relative security of employment over those in the private sector, and then compensation was in most cases, comparatively better than what obtainable in the private sector. The Association of Senior Civil Servants also suffers the same fate as the CSU. The Association of Senior Civil Servants was expected to use the Whitley council 1 for collective bargaining purposes. This class of workers represents the middle level in the civil service grade and over time they move to the highest grade. The civil servants covered by council 1 and 2 which are mainly white-collar workers see the civil service method of determining conditions of employment as a good substitute for collective bargaining. As observed by Fashoyin (1992,) petitions, deputation and lobbying were preferred to negotiation.

The unfavourable legal environment and public attitude towards unions in government, especially as regards the use of strikes, were detrimental to collective bargaining. The second inhibiting factor affects the blue-collar worker represented by council 3. The second factor was the organizational unpreparedness of the workers' unions in the public sector which makes the operation of collective bargaining to be precarious machinery. Unlike the Association of Senior Civil Servants and the CSU respectively represented by all potential middle -level and junior civil servants in the civil service, there was no solidarity among blue-collar workers. The blue-collarworkers did not enjoy much of the comfort of civil service employment. They operate in labour market which is fairly different from that of the white-collar workers. Because of this, they were militant and more responsive to trade unions 'tactics than the workers in councils 1 and 2. As observed by Fashoyin (1992), the public sector unions up to the mid-1970s were not only proliferated into ineffective units, they lacked the resources, both financial and material, to pursue their objectives to a beneficial end.

Therefore, the union that would have used the Whitley council was structurally deficient to use it to advantage and thereby rely on government paternalistic treatment of their grievances. In this regard, Fashoyin (1992) argued that many writers have demonstrated that unions in Nigeria have constantly 
preferred collective bargaining. According to him this assertion only explains the true feelings of private-sector unions. In the 1970s, most unions in the public sector have customarily embraced the formation of periodic semi-political wage commissions whose awards have, by and large, been accepted by the unions and their members

The third inhibiting factor was the lack of commitment to the principles upon which the Whitley council was based. The representatives of each side were inexperienced and unfamiliar with matters relating to employer-employee relations. And lastly, Fashoyin (1992) noted that the most damaging blow to the principle of collective bargaining as embodied in the Whitley Council was the concomitant use of the emi-political method of wage determination through special commissions or tribunals. He went further to say that the wage commission system does not bear any semblance to neither the principle of Whitleyism nor the declared official stance of the government on wage determination through collective bargaining. It is important to note that throughout the 1970s, bipartite or tripartite bargaining hardly occurs in the public sector.

It should be noted that the preference ofthe State for wage commissions was inherited from the colonial administrators. Collective bargaining in the private sector is somehow different from the process in the public sector. Otobo (2007) observed that collective agreements are industry-based though supplemented by in-plant or domestic negotiations. In the oil and gas sector, ddomesticnegotiations re important with Shell-BP as the pacesetter.

As Otobo noted further that employer in the oil and gas sector do compare notes on terms and conditions of employment. In the Food, Beverage, and Tobacco sector, the attempts are ddirected more at achieving uniform rates, narrowing differences in rates, and thus taking labour costsout of competition. In the oil and gas sector, there has always been tension and grievances over the ddisparity in the private and public sector rates (Otobo, 2007). This is because the public sector management of the Nigerian National Petroleum Commission (NNPC Group) does not have the power to negotiate directly with the representatives of workers.

In addition, the private sector oil companies have direct control over their finances and so can negotiate and determine directly with the unions, terms, and conditions of employment. A major weakness of the ccollective bargaining process in the private sector as noted by Otobo (2007) is the absence of collective agreement enforcement in a court of law. This is evident in an increased incidence of abandonment of agreements by employers especially in the public sector. Since, government as an employer and arbiter failed to demonstrate good industrial relations in the public sector by failing to honor most collective agreement, the private sector employers are increasingly following the footstep of government as an employer of labour in the country

Within the public sector in Nigeria collective bargaining is not effective as machinery for wage determination. Ghosi (1989) averred that, within the context of Nigerian industrial relations, collective bargaining is a form of direct intervention. He further noted that the Nigerian government has been directly appointing wage commissions in the determination of wages and salaries of public sector employees. In the Nigerian system of industrial relations, there is direct intervention of the government in the collective bargaining process (Ghosi; 1989). This was also evident in the explanation of Otobo (2007) that the "government is heavily involved in regulating collective 
bargaining despite its official position of being fully in support of free collective bargaining, a policy it declared publicly in 1954'. The Nigerian government as an employer has been determining public sector terms through the establishment and functioning of wages and salaries commission (Otobo;2007). To achieve this objective the government established a salaries and wages commission in order to strive to isolate the demonstration effect of private sector terms of employment to keep wage bill down (Otobo, 2007). It is pertinent to note that there were issues and challenges unresolved that have surfaced in public sector bargaining and wage determination (Otobo, 2007).

Collective Bargaining involves the employer and its representatives on the one hand, and employees and their representatives on the other (Otobo, 2013). In practice, within the Nigerian public sector the employer is not immediately visible. The public service commission and the ministry of establishment, among others, have a hand in the recruitment and discipline of public servants and yet have nothing to do with the day-to-day management of the main civil service and parastatals (Otobo, 2007). This constitutes a hindrance to the effectiveness of collective bargaining in the public sector.

Fashoyin (1992) observed that conflict of interest occurs among parties to collective bargaining in the public sector. Similarly, in the observations of Yesufu (1984) and Otobo (2007), the government is represented by the of management while workers are represented by unions. This alone is a problematic situation (Otobo, 2007). According to him, no management of a ministry is empowered to negotiate terms and conditions of employment.

As Yesufu (1984) and Ghosi (1989) observed the problem of differentiating the parties to collective bargaining is rather too cumbersome. The conditions of work as negotiated by the unions' members will affect directly the conditions of the management group. Therefore, the civil servants may be bargaining against themselves in athe long run. Ghosi (1989) supporting the stand of Yesufu (1984) opines that collective bargaining in the public sector lacks the aggressive posturing required for effective bargaining because the top civil servants perceived themselves as the government. Therefore, the competencies of the parties to the agreement reached during negotiation in the public sector become difficult to implement.

Otobo (2007), observed that in reality, the terms of the agreement may not go directly to the government. The most senior official in the affected ministry may pass the first judgment on the terms and may decide that the issue lacks merit to justify forwarding to the government and of course no need to clear terms with the ministry of establishment or public service commission. In this regard, the employer is not immediately visible in the bargaining process (Otobo; 2007), Yesufu (1984).

The issue of mandate for and during negotiations brings more clearly the consequences for collective bargaining in the public sector of the questions employers and employees are in day-to-day relations at work (Otobo;2007). The hierarchy of chain of decision-makers and approving authorities tends to limit the mandate and empowerment of negotiator representing the employer and subsequently result in lack of respect for the outcome of the negotiation process by the ultimate employer in the public sector (Otobo;2007) 
The ultimate employer in the public sector has the right to accept, modify or even reject the terms of the agreement reached (Fashoyin; 1992). This may undermine the goodwill and encourage the growth of distrust and adversarial relations (Otobo; 2007). In addition, the public sector employer at all level may refuse to negotiate, and when forced by circumstances or out of rational choice to do so, they resent the counter-offers and demand of the other parties, and also maintains the right to have a final say as the state/government (Otobo, 2007). However, the government derived legitimacy fromthe doctrine of sovereignty, which rest on the idea that government representssovereign power and as such only the government could determine the terms and conditions of employment in the public sector including wage issues (Ghosi; 1989, Fashoyin; 1992, Otobo; 2007). This was also observed in the Morgan commission (1964, para 103) thus "it appears that in dealing with their employees, the government are unduly conscious of their prerogative to determine the levels of remuneration and condition of service, irrespective of their acceptability to the workers"

For these reasons, the government usually reneges or goes back on the agreement without feeling any great sense of responsibility for subsequent conflict situations or that breach of agreement is sanctionable (Otobo, 2007).

\section{Challenges of Public Sector Wage Bargaining in Nigeria}

Within the Nigerian public sector integrity issues is very critical but without cognizance. This explains why collective agreement reached is not respected especially by the Nigerian government. Otobo (2007) noted that the bargaining process is characterized by blatant disregard for the agreement reached and procedures are dominated by conflicts and low trust relations between the parties involved in collective bargaining. In support of Otobo (2007) stand on these issues Aiyede (2002), Adesola (2004) observed that public sector wages have been set through government fiat or quasi- political wages commissions or tribunals largely set up by the government. According to them, the implementation of the agreement on wages, reached through the machinery for nationwide negotiation that has predominated in the public sector, has often been chaotic, attended by controversies, agitations and widespread strikes, costing the country enormous resources in terms of man-days lost.

Similarly as observed by Fajana (2018) that The current pay policy in Nigeria confers on the NSIWC, the central role of regulating the salary administration system in the Federal Public Service, except in the case of remuneration of officers covered by the (Certain Political, Public and Judicial Office Holders (Salaries, Allowances, etc) Act in performing these functions assigned to it by law, NSIWC periodically carries out pay surveys to establish pay differentials between the public and private sectors. Sometimes, it is done to establish the differentials between the self-funded agencies and the treasury-funded agencies in the public sector. However, the commission is challenged by policy and procedure in the public sector. For instance, as noted by Fajana (2018) There is always a provision in the enabling laws of many agencies which give their Boards the power to determine their staff remuneration.

In most instances, collective agreements are not restricted to those workers whose union representatives entered them. They are cloned and operated by some others on the excuse that all the workers involved belong to the same union. For example, a collective agreement entered into by the 
Nigerian National Petroleum Corporation Management and the local chapter of NUPENG and PENGASSAN can be adopted wholly by the Petroleum Equalization Fund (PEF), PTDF, PPPRA, DPR etc without regard to the peculiarities of each agency which ought to be evaluated at the bargaining table and remunerated differently. It would appear that there is a need to demarcate/define the coverage of each bargaining unit (even as an item on the agenda of the negotiating parties) to minimise this trend.

Salary differentials and salary relativities rather than the cost of living have tended to drive the demand for wage adjustment at the bargaining table which tends to make the exercise of wage adjustment perennial. The present minimum wage policy that legislates, a common uniform minimum wage floor across the country was made acrimonious by the insistence of union leaders that its implementation should result in an across-the-board salary adjustment for everyone. This position contrasts with the evidence from practices across the globe. Even the objection by some state governments to the federally-enacted minimum wage is only one option. In its simplest form, a minimum wage act simply prohibits employers of labour from hiring workers for less than a given hourly, daily, weekly, or monthly minimum wage.

Another crucial issue in the public sector wage bargaining is the deregulation of collective bargaining. In reality, as noted by Otobo, there has been no deregulation of collective bargaining. In the public sector no ministry or parastatals has the autonomy to negotiate binding terms with employees. For instance, the attempts by Academic Staff Unions of Universities (ASUU) to negotiate with individual university councils gravely undermined by circular to the universities authorities imposing an upper ceiling in increases of basic salaries; it was a centralized system and ASUU responded by opting to negotiate directly with the approving authority. Similarly, NNPC hands over all proceeds from the sale of crude oil to the federal government and thus has no independent finances to operate in the manner of Shell or Total or Chevron, Texaco (Otobo;2007).

However, in most cases, the use of this wage machinery drives the government to use its prerogative to amend the collective agreement to its advantage. As a consequence, there are reactions from trade unions in the form of protests, strikes, and demonstrations. In 2014, the Academic Staff Union of Universities (ASUU) embarked on six months strike action to push home its grievance on nonimplementation of the 2009 collective agreement with the Federal Government of Nigeria. Similarly, the National Union of Research Institutions (NURI) went on an industrial strike for over a year to protest the non-implementation of the 2008 agreement on the condition of work, remuneration and unpaid allowances (Elegbede, 2016).

Historically, since the colonial era, collective bargaining as machinery for wage determination in the public sector appears to prevent the unilateral imposition of wages on the union by the government and vice versa as the case may be. However, it is not often used by the Nigerian government to determine wages. Therefore, collective bargaining appears ineffective as a potent tool for wage determination in Nigeria's public sector. 


\section{Conclusion and Recommendations}

This study revealed that collective bargaining machinery lacks rigorous effectiveness in the Nigeria Public Sector because of government regulations and intervention. The federal government reserved the rights to accept, amend or reject the collective agreement reached between representatives of government and trade unions which seriously undermined effective use of collective bargaining as machinery and process in wage determination and condition of services of the civil servants.

The challenges facing collective bargaining posed some threats to the effectiveness of public sector administration because workers in that sector tend to increase negative reactions and covert expression of grievances in response to poor conditions of work, pay, and remuneration.

This study recommends the following course of actions for the effectiveness of the collective bargaining system in Nigeria;

i. Governments should honour the collective agreement by ensuring effective implementation of the collective agreement at all levels (national, state and local). Effective implementation of the collective agreement will likely reduce trade unions negative reactions such as strike, protests and demonstrations. Employers in the public sector should ensure adequate consultation with trade unions when formulating wage commission policy. Public sector employers should ensure involvement of trade unions in wage determination processes especially before implementation of wage commission policy.

ii. Government should avoid the use of unfair labour management practices during collective bargaining process to undermine effective implementation of the collective agreement. The government at all level in the federation should be involved in wage determination processes and during the implementation phase.

iii. Trade unions should adopt innovative strategies to ensure the stability of workers' organization in other to equate their bargaining power with that of the management in the Nigerian public sector. Furthermore, stability of trade unions will enhance the use of strike actions to reinforce their bargaining power.

\section{References}

Adesola, A. (2011). Trade union leadership structure and the challenges of succession politics. Paper presented at the sixth IIRA African regional congress of Industrial Relations. University of Lagos.

Aiyede, E. (2002). Decentralizing public sector collective bargaining and the contradictions of federal practice in Nigeria, African study monographs, Development Policy Center, Ibadan, Nigeria 23(1), 11-29.

Akinwale, A. and Elegbede, S. (2016). Trade unions reactions to wage determination processes in the public sector of Lagos. Journal of Innovative Research in Business \& Economics, 1(1), 1-49

Akinwale, A. (2011). Labor reform and industrial conflict management in Nigeria. Paper presented at the sixth IIRA African regional congress of Industrial Relations. Lagos: University of Lagos. 
Aminu, A. (2011). Government wage review policy and public -private sector wage differential in Nigeria, African Economic Research Consortium, AERC Research paper.

Anusionwu, E. (1983). The distribution of personal income in the Nigeria public sector. Indian Journal of Industrial Relations, 18 (1), 307-324.

Anyim, F., Olusanya, O., and Ekwoaba, J. (2014). Collective bargaining in the Nigerian chemical rubber and non-metallic products industry, International Review of Social Sciences and Humanities, 7 (1), 35-45.

Anyim, F. and Elegbede, T. (2012). Collective bargaining dynamics in the Nigerian public and private sectors. Nigerian Journal of Labour and Development Studies, 1(2), 125-136

Ayobami, A. (2010). Influence of extrinsic and intrinsic motivation on employees' performance. Paper presented at the sixth IIRA African regional congress of Industrial Relations, University of Lagos.

Chidi, C. (2014). Collective bargaining and dispute settlement in food beverages and tobacco industry in Lagos State, Nigeria. European Journal of Business and Management, 6(2), 2222-2839

Elegbede, T. and Shadare, S, (2018). Theoretical explanation of wage determination process in the Nigeria Public Sector. Advances in Management, 17(1),165-180

Fajana, S. (2018). Public sector remuneration issues in Nigeria and remedies, Paper Presented at the Celebration of the $25^{\text {th }}$ Anniversary of the National Salaries, Incomes and Wages Commission;

The Symposium on Effective Management of Remuneration and Allied Processes in the Nigerian Public Service,

Fajana, S. (2000). Functioning of the Nigerian labormarket,Labofin and Company.

Fajana, S. (2002). Industrial relations in Nigeria: Theories and features. Labofin and Company.

Fajana, S. (1991). Ascriptive influence on pay and employment conditions: A Survey of British Multinationals and Indigenous Employers in Nigeria.International Journal of Human Resource Management.

Fajana, S. (1989). The System approach as theory for multinational industrial relations in developing Countries, Relations Industrelles, 44(3), 615-634.

Fashoyin, T. (1992). Industrial relations in Nigeria, Longman Nigeria Plc

Fashoyin, T. (1990). Incomes and inflation in Nigeria, Indian Journal of Industrial Relations, 25(4), 407-410

Fashoyin, T. (1986). Trade unions and economic development in Africa. International journal of Management and Organization, 16(2), 59-78 
George, O. (2011). The impact of culture on the transfer of management practices in former British colonies: A comparative case study of Cadbury (Nigeria) and Cadbury Worldwide, United States of America: Xlibris Corporation

George, O (2010). Culture the rejected jewel in the transfer of management practices: culture, the "the rejected jewel "in the transfer of management practices in former British colonies (case of Cadbury), Germany: Lambert Academic Publishing

Ghosi, A. (1989). Collective Bargaining in Nigeria, Indian Journal of Industrial Relations, 25 (2), 157-168.

Ige, K., Adeyeye, F., and Aina, S. (2011). An empirical study of the factors influencing industrial conflicts in Nigeria.EuropeanJournal of Humanities and Social Sciences, 10(1), 1-18

Iwunze, V. (2013). The unenforceability of collective agreements under Nigerian labor jurisprudence: The paradox of agreement without agreement. International Journal of Advanced Legal Studies and Governance,4(3), 2-13

Nwude, E. (2013). The politics of minimum wage in Nigeria: The unresolved issues. Asian Journal of Empirical Research, 3(4), 477-492. Retrieved from http: //aessbweb/ journal.editorial.php? Id=5004

Omisore, B. (2011). Breached agreement: threat to management union relationship. The Social Sciences, 6(4), 299-306

Otobo, D. (2007) contemporary industrial relations in Nigeria in Geoffrey, W (eds) Industrial Relations in Africa, Palgrave Macmillan, 162-178

Otobo, D. (2002). Industrial relations: theories and controversies, Malthouse Press Limited

Otobo, D. (1986). Bureaucratic Elites and Public Sector Wage Bargaining in Nigeria.The Journal of Modern African Studies, 24(1), 101-126. Retrieved from http://www.jstor. Org/stable/160514

Otobo, D., and Omole, M. (1987). Readings in industrial relations in Nigeria, Malthouse Press Limited

Oyebade, W (2015 June). Nigeria medical association strike action in Lagos State Public Sector, Guardian Newspaper

Salawu, B., Hassan, A., and Adefeso, A. (2013). Workers government wage relations and the unresolved issues of income inequality and labor strikes in Nigeria: Suggestions for the way forward. Journal of Public Administration and Policy Research, 5(3), 61-67

Yesufu, T. (1984). The dynamics of industrial relations: The Nigerian experience. University Press Limited. 